\title{
Seroprevalence of Hepatitis $A$ in Children Followed-up with the Diagnosis of Chronic Hepatitis B Infection
}

\author{
Kronik Hepatit B Enfeksiyonu Nedeniyle Takip Edilen Çocuklarda Hepatit A \\ Seroprevalansı
}

\author{
(1) Uğur Deveci , (1) Ufuk Acar² \\ ${ }^{1}$ Firat University Faculty of Medicine, Department of Pediatric Gastroenterology, Elazığ, Turkey \\ 2Suruç District Public Health Directorate, Department of Public Health, Şanlıurfa, Turkey
}

\begin{abstract}
Objectives: To investigate the seroprevalence of hepatitis A virus (HAV) infection in children with chronic hepatitis B virus (HBV) infection and to immunize patients who did not have anti-HAV immunoglobulin (lg) $\mathrm{G}$ level in protective titer.

Materials and Methods: A retrospective analysis was made in 79 children with chronic HBV infection between January 2017 and December 2018.

Results: Of the patients with a mean age of $11.5 \pm 4.6$ years (1-18 years), $64.6 \%$ were boys and $35.4 \%$ were girls (male/ female=51/28). Anti-HAV (lg) $G$ was positive in $72.2 \% \quad(n=57)$ of the cases. According to gender, the rate of sero-positivity was found to be $72.5 \%(n=37)$ in boys and $71.4 \%(n=20)$ in girls. HAV immunization was determined at the lowest rate $(8.1 \%)$ in the $14-18$ years age group. Although 3 patients vaccinated against HAV were anti HAV-lgG negative, and 39 patients who were not vaccinated were anti-HAV IgG positive.

Conclusion: The seroprevalence of HAV should also be evaluated in children with chronic HBV infection. Morbidity and mortality due to HAV infection can be prevented by vaccinating non-immune patients.

Keywords: Chronic hepatitis B infection, hepatitis A virus, super infection, seroprevalence, child
\end{abstract}

ÖZ

Amaç: Kronik hepatit B virüs (HBV) enfeksiyonu olan çocuklardaki hepatit $A$ virüs (HAV) enfeksiyonu seroprevalansının araştırıması ve koruyucu titrede anti-HAV immünoglobulin (lg) G düzeyine sahip olmayan hastaları bağışıklama amaçlanmıştır.

Gereç ve Yöntemler: Ocak 2017 ile Aralık 2018 tarihleri arasında kronik HBV enfeksiyonu tanısı ile izlenen 79 çocuk hastanın tıbbi kayıtları geriye dönük olarak incelendi.

Bulgular: Yaş ortalaması $11,5 \pm 4,6$ yıl (1-18 yıl) olan hastaların $\% 64,6$ 'sı erkek, \%35,4'ü kız idi (Erkek/Kadın=51/28). Olguların $\% 72,2$ 'sinde ( $n=57)$ anti-HAV immünoglobulin (lg) G pozitif bulundu. Cinsiyete göre, sero-pozitiflik oranının erkeklerde $\% 72,5 \quad(n=37)$, kızlarda ise \%71,4 (n=20) oranlarında olduğu belirlenmiştir. On dört-18 yaş grubu olgularda HAV bağışıklamasının en düşük oranda $(\% 8,1)$ olduğu tespit edilmiştir. HAV'ye karşı aşılanmış 3 hastada anti HAV-lgG negatif olmasına karşın, aşılanmamış 39 hastada anti-HAV IgG pozitif bulundu.

Sonuç: Kronik HBV enfeksiyonu olan çocuklarda HAV seroprevalansının da değerlendirilmesi gerekir. Bağışık olmayan hastaların aşılanması ile HAV enfeksiyonuna bağlı morbidite ve mortalite önlenebilir.

Anahtar Kelimeler: Kronik hepatit B enfeksiyonu, hepatit A virüsü, süper enfeksiyon, seroprevalans, çocuk

Deveci U, Acar U. Seroprevalence of Hepatitis A in Children Followed-up with the Diagnosis of Chronic Hepatitis B Infection. Viral Hepat J. 2020;26:74-77. 


\section{Introduction}

Although hepatitis A virus (HAV) infection is widespread throughout the world, in developing countries in particular it continues to be a signifcant public health problem (1). HAV leads to different clinical tables ranging from asymptomatic infection to fulminant hepatitis (2). HAV infection may not always show a classic course and acute liver failure may be seen in approximately $1 \%$ of cases. Acute liver failure is seen more often when there is an underlying liver disease or chronic hepatitis B infection (3).

Chronic hepatitis B virus (HBV) infection in children can be confused with acute viral hepatitis associated with HAV super infection. Compared with healthy children, HAV super-infection in patients with chronic HBV infection can lead to higher morbidity and mortality (4). Fulminant liver failure may be seen more often in these cases (5). Therefore, children followed up with a diagnosis of chronic HBV infection should be evaluated in respect of immunity to HAV infection and children who are not immune should be vaccinated (6).

The aim of this study was to investigate the seroprevalence of $\mathrm{HAV}$ in children being followed up with a diagnosis of chronic HBV infection and to immunise patients who did not have an anti-HAV immunoglobulin (lg) G level at a protective titer. It was also planned to screen family members of cases with chronic HBV infection and vaccinate those who were not immune to HBV.

\section{Materials and Methods}

Approval for this retrospective cohort study was granted by the Non-Interventional Research Ethics Committee of Firat University (approval number:13/14, date:19.07.2018). A retrospective examination was made of the medical records of 79 paediatric patients who were followed up with a diagnosis of chronic HBV infection in the Paediatric Gastroenterology Department of Şanlıurfa Training and Research Hospital between January 2017 and December 2018. The clinical and laboratory data obtained were recorded on forms prepared for the study. The patients were separated into 3 age groups as 1-6 years old, 7-13 years old, and 14-18 years old.

\section{Statistical Analysis}

Data obtained in the study were analysed statistically using IBM-SPSS vn. 22 software. Variables were stated as mean \pm standard deviation values, or number and percentage (\%). The chisquare test was used in analyses. A value of $p<0.05$ was accepted as statistically significant.

\section{Results}

The cases included in the study all had hepatitis B surface antigen (HBsAg) positivity for longer than 6 months. The whole patient group of 79 children comprised 51 (64.6\%) boys and 28 $(35.4 \%)$ girls with a mean age of $11.5 \pm 4.6$ years (range, 1-18 years). Of these cases, $16(20.3 \%)$ were in the $1-6$ years age group, 26 (32.9\%) were in the $7-13$ years age group and 37 (46.8\%) were in the 14-18 years age group. The median HBsAg level was determined as $1022 \mathrm{lU} / \mathrm{mL}$ (Table 1).

\begin{tabular}{|l|l|}
\hline \multicolumn{2}{|l|}{ Table 1. Distribution of the cases by age and gender } \\
\hline \multicolumn{2}{|l|}{} \\
\hline Gender $(\%)$ \\
\hline Female & $28(35.4)$ \\
\hline Male & $51(64.6)$ \\
\hline Age & $16(20.3)$ \\
\hline $1-6$ years & $26(32.9)$ \\
\hline $7-13$ years & $37(46.8)$ \\
\hline $14-18$ years &
\end{tabular}

Anti-HAV lgG positivity was determined in $72.2 \%(n=57)$ of all the cases. According to gender, the anti-HAV IgG seroprevalence was found to be $72.5 \%(n=37)$ in boys and $71.4 \%(n=20)$ in girls. The hepatitis $A$ immune status of the cases according to age is shown in Table 2. As the 1-6 years age group coincided with the introduction of the hepatitis A routine vaccination program in October 2012, 15 (93.8\%) of the 16 cases in that group had been vaccinated. The 39 (49.33\%) patients not vaccinated against HAV were thought to have had subclinical or asymptomatic HAV infection.

When comorbidities were examined, 2 (2.5\%) cases with chronic HBV infection were found to have hepatoblastoma (these patients had undergone liver transplantation), 1 (1.3\%) of which had cerebral palsy, and the other 1 (1.3\%) had thalassemia major. Anti-HAV lgG positivity was determined in both of these patients. Lamivudine was being used by 4 patients because of chronic HBV infection, tenofovir by 2 patients and adefovir by one patient. Three of these patients were determined with anti-HAV IgG positivity. The 4 cases without immunity to HAV infection were administered Hepatitis A vaccination.

\section{Discussion}

As a result of improved socio-economic and hygiene conditions in Turkey in recent years and the inclusion of hepatitis $A$ vaccination into the routine vaccination program, acute viral HAV infection has significantly decreased. Consequently, HAV infection has shifted to adolescents and adults (7).

\begin{tabular}{|l|l|l|l|}
\hline Table 2. Hepatit A seroprevalence according to the age groups \\
\hline \multirow{2}{*}{ Age group } & Hepatit A seroprevalence & Vaccinated (n, \%) & Total (n, \%) \\
\cline { 2 - 4 } & Not vaccinated $(\mathbf{n}, \%)$ & $15(93.8)$ & $16(20)$ \\
\hline $1-6$ years & $1(6.3)$ & $3(11.5)$ & $26(33)$ \\
\hline $7-13$ years & $23(88.5)$ & $3(8.1)$ & $37(47)$ \\
\hline $14-18$ years & $34(91.9)$ & & \\
\hline$\chi 2=46,472, p=0.0001$ & & \\
\hline
\end{tabular}


HBV infection continues to be a significant public health problem throughout the world in general (8). Chronic HBV infection is seen in approximately 400 million people $(5 \%$ of the global population) (9). Hepatitis B vaccination was included in the national vaccination program in Turkey in 1998. Although a reduction has been seen in the seroprevalence of chronic HBV infection with the implementation of HBV vaccinations, this infection is still encountered in children (10).

HAV infection generally has a mild clinical course but in those with chronic HBV infection, it may show a worse course (11). Therefore, children and adolescents with chronic HBV infection should be evaluated in respect of immunity to HAV infection, and those without immunity should be vaccinated (9).

The majority of the cases in this study followed up for a diagnosis of chronic HBV infection were seen to be children or adolescents in the 14-18 years age group, who were born before the inclusion of hepatitis $B$ vaccination in the national vaccination program. This finding can be accepted as a sign of the success of routine hepatitis B vaccination in Turkey. There has also been seen to be a significant reduction in chronic $\mathrm{HBV}$ infection in children as a result of increased awareness of $\mathrm{HBV}$ infection together with the implementation of vaccinations (10).

Anti-HAV IgG positivity was determined in $72.2 \%$ of the cases in this study followed up with a diagnosis of chronic HBV infection. Of the cases determined with anti-HAV IgG positivity, 15 had been included in the national vaccination program and 6 had been vaccinated for hepatitis $A$ by their family. The 39 cases that had not been vaccinated were thought to have had subclinical or asymptomatic HAV infection.

When evaluation was made according to age groups, anti-HAV IgG positivity was seen most (75\%) in the 1-6 years age group. Of the 4 cases in this age group with anti-HAV IgG negativity, 1 had not been vaccinated, and the other 3 had not formed antiHAV IgG positivity at a protective titer despite vacination. In the 7-13 years age group, anti-HAV IgG positivity was determined in $53.8 \%$. Three of the children in this age group had been vaccinated by their families and the other 11 children were thought to have had subclinical or asymptomatic HAV infection. In the 14-18 years age group, $83.8 \%$ were determined to have immunity to HAV. In this age group, 3 children had been vaccinated by their families and the other 28 children were thought to have had subclinical or asymptomatic HAV infection. The course of HAV infection in childhood is generally benign. In more than $70 \%$ of cases the clinical course is asymptomatic, but occasionally it can progress to liver failure (12). In the current study, anti-HAV IgG positivity was seen to increase together with age, which was consistent with the findings of other studies (7).

In a previous study in Turkey, conducted in Ankara, HAV seroprevalence in patients diagnosed with chronic HBV infection was reported to be $34 \%$ in the group aged $<20$ years (13). In another multicentre study in Turkey, positive hepatitis A seroprevalence was determined at the level of $73.8 \%$ in patients $<19$ years old who were followed up for chronic hepatitis B infection (14). A study in Konya reported hepatitis A seroprevalence as $28 \%$ in cases followed up for chronic HBV infection and aged $<20$ years (15). Together with these findings, the higher hepatitis A seroprevalence in the current study was thought to be due to differences between regions. It could also be attributed to the fact that our hospital is located in a region of Sanlıurfa which has been recently settled, has a large number of refugees, a low socio-economic level and insufficient infrastructure.

Shavakhi et al. (16) determined positive hepatitis A seroprevalence in $71.4 \%$ of Iranan cases aged $10-20$ years who developed chronic liver disease because of viral or autoimmune hepatitis and Wilson's disease. In a study in Korea by Kim et al. (17), positive hepatitis A seroprevalence was determined at the rate of $22.2 \%$ in cases aged $<20$ years who were followed up for chronic HBV infection, and it was stated that hepatitis A seroprevalence increased with age. In another study in Korea, Lee et al. (18) reported zero positive hepatitis A seroprevalence in cases aged 11-20 years who were followed up with a diagnosis of chronic hepatitis B. The seroprevalence of hepatitis A has been reported at the levels of $9.8 \%$ in the 21-30 years age group, $46.3 \%$ in the $31-40$ years age group and $94.9 \%$ in cases aged $>40$ years. Although complications are not seen in the course of HAV infection in the majority of cases, there are cases that have developed acute liver failure. Accordingly, children with chronic HBV infection are at a higher risk than the normal population of developing acute liver failure associated withh HAV super infection.

\section{Study Limitations}

The limitations of our study were its retrospective nature and short study period.

\section{Conclusion}

Children diagnosed with chronic hepatitis B should be evaluated in respect of immunity to HAV infection. With vaccinations of those without immunity, the morbidity and mortality associated with HAV super infection, which can be seen in these patients, can be prevented. In respect of community health, the family members of patients diagnosed with chronic HBV infection should be evaluated in respect of HBV infection, and those without immunity should be vaccinated.

\section{Ethics}

Ethics Committee Approval: This study was approved by the Ethics Committee of Firat University Faculty of Medicine (approval number: 13/14, date: 19/07/2018).

Informed Consent: Informed consent was not obtained from the parents of the patients in this study because of the retrospective nature of the study.

Peer-review: Externally peer-reviewed.

\section{Authorship Contributions}

Data Collection and/or Processing: U.D., U.A., Analysis and/ or Interpretation: U.D., U.A., Literature Search: U.A., U.D., Writing Manuscript: U.D.

Conflict of Interests: The authors have no conflict of interests to declare.

Financial Disclosure: The authors declared that this study received no financial support.

\section{References}

1. Yazigi N, Balistreri WF Viral Hepatitis. In: Kliegman RM, Stanton BF, St. Geme III JW, Schor NF, Behrman RE (eds.), Nelson Textbook 
of Pediatrics. 19th ed. Philadelphia: Elsevier Saunders. 2011; p. 1393-1404.

2. Jeong $\mathrm{SH}$, Lee HS. Hepatitis A: Clinical manifestations and management. Intervirology. 2010;53:15-19.

3. Chu J, Arnon R. Other viral infections. In: Kleinman RE, Goulet OJ, Vergina GM, Sanderson IR, Sherman PM, Shneider BL (eds.), Walker's Pediatrics Gastrointestinal Disease. 6th ed. North Carolina, People's Medical Publishing House. 2018; p.1291-1302.

4. Keeffe EB. Acute hepatitis A and B in patients with chronic liver disease: prevention through vaccination. Am J Med. 2005;118(Suppl 10A):21S-27S

5. Ahmad F, Hamzah NAC, Mustaffa N, Gan SH. Anti-hepatitis A seroprevalence among chronic viral hepatitis patients in Kelantan, Malaysia. World J Gastroenterol. 2011;17:4130-4134.

6. Khudyakov Y, Francisco A, Bell BP. Hepatitis A virus. In: Mandell GL, Bennett JE, Dolin R (eds.), Mandell, Douglas, and Bennett's Principles and Practice of Infectious Diseases. 8th ed. Philadelphia, PA: Elsevier; 2015; p. 2095-2112.

7. Türker K, Balcı E, Batı S, Hascuhadar M, Savaş E. The changing epidemiology of hepatitis A infection in Turkey. Journal of Turkish Society of Microbiology. 2011;41:143-148.

8. Daniels D, Grytdal S, Wasley A; Centers for Disease Control and Prevention (CDC). Surveillance for acute viral hepatitis - United States, 2007. MMWR Surveill Summ. 2009;58:1-27.

9. Karnsakul W, Schwarz KB. Hepatitis B and C. Pediatr Clin North Am. 2017;64:641-658.

10. Altan H, Demirtaş S, Taş D, Budakoğlu II. [The Evaluation of Hepatitis B Seroprevalence in Children Applied to a State Hospital in Ankara]. Ankara Med J. 2017;1:1-8.

11. Kim JI, Kim YS, Jung YK, Kwon OS, Kim YS, Ku YS, Choi DJ, Kim $\mathrm{JH}$. Factors influencing the severity of acute viral hepatitis $A$. Korean J Hepatol. 2010;16:295-300.
12. Fiore AE, Wasley A, Bell BP; Advisory Committee on Immunization Practices (ACIP). Prevention of hepatitis A through active or passive immunization: recommendations of the Advisory Committee on Immunization Practices (ACIP). MMWR Recomm Rep. 2006;55:1-23.

13. Tulek N, Ozsoy M, Moroglu C, Cagla Sonmezer M, Temocin F, Tuncer Ertem G, Sebnem Erdinc F. Seroprevalence of hepatitis A virus antibodies among the patients with chronic hepatitis $B$ in Turkey. Euroasian J Hepatogastroenterol. 2015;5:95-97.

14. Celen MK, Turker K, Oztoprak N, Sener A, Tuna N, Ince N, Erdem I, Saltoglu N, Ozdemir D, Dal T, Karahocagil MK, Sirmatel F, Akcam FZ, Polat FE, Cabalak M, Sacar S, Tosun S, Tabak F. The evaluation of exposure to hepatitis A virus in HBsAg-positive persons: a multicenter study from Turkey. J Pure Appl Microbiol. 2014;8:3063-3068.

15. Özden HT. Hepatitis A seroprevalence in patients with chronic viral hepatitis in Konya, Turkey. Eur J Gastroenterol Hepatol. 2016;28:333-337.

16. Shavakhi A, Somi MH, Farhang S, Majidi G, Majidi T, Pouri AA. Prevalence of hepatitis $A$ in Iranian patients with chronic liver disease. Iran J Clin Infect Dis. 2008;3:189-192.

17. Kim DY, Ahn SH, Lee HW, Kim SU, Kim JK, Paik YH, Lee $\mathrm{KS}$, Han KH, Chon CY. Anti-hepatitis A virus seroprevalence among patients with chronic viral liver disease in Korea. Eur $\mathrm{J}$ Gastroenterol Hepatol. 2007;19:923-926.

18. Lee SH, Kim HS, Park KO, Park JW, Chun SY, Lim SJ, Cho HJ, Kim SJ, Park HW, Moon HK, Shin WG, Kim KH, Jang MK, Lee JH, Kim $\mathrm{HY}$. Prevalence of IgG anti-HAV in patients with chronic hepatitis B and in the general healthy population in Korea. Korean $\mathrm{J}$ Hepatol. 2010;16:362-368. 